\title{
PENGARUH BRAND COMMUNICATION TERHADAP CUSTOMER LOYALTY DENGAN CUSTOMER BASED BRAND EQUITY DAN CUSTOMER VALUE SEBAGAI VARIABEL INTERVENING PADA PT. PLATINUM CERAMICS INDUSTRY DI SURABAYA
}

\author{
Youvita Calista \\ Pengamat Merk di Surabya \\ E-mail: youvitacalista@gmail.com
}

\begin{abstract}
Abstrak: Penelitian ini bertujuan untuk menganalisis pengaruh Komunikasi Merek (Tenaga Pemasar, Iklan, Pameran Dagang, Pemasaran langsung) terhadap Loyalitas Pelanggan pada PT. Platinum Ceramics Industry di Surabaya dengan Pelanggan Berdasarkan Ekuitas merk dan Nilai Pelanggan sebagai intervensi variabel. Dilakukan dengan menyebarkan kuesioner kepada 100 toko yang menjual produk Platinum di Surabaya. analisis kuantitatif dengan metode model analisis jalur digunakan untuk analisis teknis.
\end{abstract}

Kata kunci: Komunikasi merek, pelanggan berdasarkan ekuitas merk, nilai pelanggan, loyalitas pelanggan

\begin{abstract}
This research aimed to analyze the effects of Brand Communication (Sales Force, Advertising, Trade Shows, Direct Marketing,) towards Customer Loyalty at PT. Platinum Ceramics Industry in Surabaya with Customer Based Brand Equity and Customer Value as intervening variable.This research was conducted by distributing questionnaires to 100 stores that sell Platinum's product in Surabaya. Quantitative analysis with path analysis model method were used for the techinal analysis.
\end{abstract}

Keywords: Brand communication, customer based brand equity, customer value, customer loyalty

\section{PENDAHULUAN}

Industri keramik Indonesia telah berkembang selama lebih dari 30 tahun dan memberikan kontribusi signifikan dalam mendukung pembangunan nasional.Namun masuknya perekonomian global telah berdampak pada penurunan konsumsi keramik nasional sebesar 110 jt $\mathrm{m} 2$ dari tahun 2015-2016. Untuk mencegah terjadinya penurunan yang berkelanjutan, pemerintah melalui Komite Percepatan Penyediaan Infrastruktur Prioritas (KPPIP) sedang mencanangkan 225 proyek strategis nasional dan 30 proyek infrastruktur prioritas senilai $\mathrm{Rp}$ 851.000.000.000,00 lebih sepanjang tahun 20152019 ini (“Inilah 30 proyek besar.."22 Februari 2016).

Salah satu proyek yang dapat menjadi peluang besar bagi para pelaku di industri keramik adalah proyek Satu Juta Rumah. Dalam proyek ini kota Surabaya terpilih sebagai kota terbesar kedua dengan jumlah 26.171 rumah tapak dan 1.200 rumah sederhana. Ini membuktikan bahwa kota Surabaya memiliki prospek pembangunan property dan konstruksi yang akan terus berkembang kedepannya.Beragam proyek pemerintah ini menjadi peluang besar bagi para produsen keramik di Indonesia karena akan banyak dibutuhkan jenis tiles/ubin untuk proyek pembangunan property tersebut. Setelah semua unit bangunan telah dipasarkan dan siap dihuni, tentunya para pemilik rumah akan melakukan renovasi pada tiap unit rumah yang dihuninya dan kebanyakan masyarakat akan cenderung mengunjungi toko-toko retail yang menjual beragam perabot rumah tangga.

Bagi perusahaan, memiliki banyak retailer tentunya menjadi keuntungan tersendiri, karena lokasi para retailer yang tersebar di berbagai daerah memungkinkan perusahaan untuk menjangkau lebih banyak customer, melebarkan pasarnya, serta tidak menutup kemungkinan pada peningkatan penjualan kedepannya. Oleh karena itu penting bagi para produsen keramik untuk menjalain hubungan yang erat dengan para retailer dan memastikan bahwa para retailer tetap mengingat brand mereka sebagai salah brand terbaik dalam kategori produk keramik.

Salah satu produsen keramik terbesar di Surabaya adalah PT. Ceramics Industry (PCI). Tanpa adanya hubungan kerjasama yang baik antara perusahaan dengan para retailer tentu mustahil bagi PCI untuk mencapai kedudukannya di pasar saat ini.Salah satu cara yang dapat digunakan oleh perusahaan untuk menjaga hubungan baik dengan para customer adalah dengan melakukan Brand Communication.

Brand Communication dinyatakan sebagai suatu elemen utama yang digunakan untuk mengelola hubungan antara brand dengan customer, pegawai, supplier, channel member, media, peraturan pemerintah, dan komunitas (Zehir et al., 2011). 
Pemilihan media komunikasi yang tepat tentunya akan berpengaruh besar terhadap terciptanya Brand Communication yang sempurna, dimana dari aktivitas komunikasi inilah customer dapat mengalami dan memahami nilai dan kekhasan dari produk dan jasa yang diberikan oleh perusahaan. Baik dan buruknya pemahaman customer mengenai brand akan berdampak pada Customer Based Brand Equity.

Customer Based Brand Equity positif yang dihasilkan dari pemahaman dan pengetahuan customer mengenai brand tentunya akan memberikan keuntungan tersendiri kepada perusahaan. Salah satunya adalah customer lebih tidak sensitif terhadap kenaikan harga (Keller, 2012). Selain berdampak pada Customer Based Brand Equity, Brand Communication yang tepat juga membantu perusahaan untuk mengetahui sejauh mana manfaat yang dirasakan oleh customernya.

Customer Value merupakan nilai yang dirasakan oleh pelanggan, dimana penilaian tersebut merupakan penilaian keseluruhan konsumen dari kegunaan produk berdasarkan persepsi tentang apa yang diterima dan apa yang diberikan (Zeithaml, 1988). Dilakukannya beragam aktivitas brand communication ini membantu perusahaan mengetahui seberapa besar manfaat functional maupun emotional yang dirasakan oleh pelanggan, sehingga membentuk perspektif customer tentang brand serta memastikan bahwa customer mendapatkan kepuasan yang optimal, maka hal ini akan membawa perusahaan pada tingginya tingakat loyalitas dari para customer.

Berdasarkan pada latar belakang diatas, maka dari itu peneliti ingin meneliti pengaruh Brand Communication terhadap Customer Loyalty melalui Customer Value dan Customer Based Brand Equity pada PT. Platinum Ceramics Industry di Surabaya.

\section{Tujuan penelitian}

Tujuan penelitian adalah pengaruh Brand Communication terhadap Customer Loyalty melalui Customer Value dan Customer Based Brand Equity pada PT. Platinum Ceramics Industry di Surabaya.

\section{URAIAN PENELITIAN}

\section{Brand Communication}

Komunikasi merupakan suatu aktivitas yang dilakukan oleh manusia untuk dapat terikat bersamasama dan menciptakan sebuah hubungan (Azize, Cemal, and Hakan, 2012).
Lynch dan Chernatony (2004) berpendapat bahwa Brand merupakan kelompok nilai-nilai functional dan emotional yang menjanjikan pengalaman yang unik dan dapat diterima antara pembeli dan penjual, baik dalam konteks B2B maupun B2C. Nilai-nilai emosional ini sendiri dapat mempengaruhi pengambilan keputusan organisasi, oleh karena itu penting bagi perusahaan untuk memperhatikan bagimana nilai dari brand tersebut dikomunikasikan baik dalam internal organisasi maupun ekternal organasasi.

Menurut Lynch dan Chernatony (2004) ada beberapa tipe media yang dapat digunakan perusahaan untuk mengkomunikasikan brandnya kepada para customer (External Brand communication), yaitu Personal Selling, Advertising, Trade Show, Direct Marketing, Internet. Dimensi dari Internal maupun eksternal brand communication ini dapat dilihat pada Gambar 1.

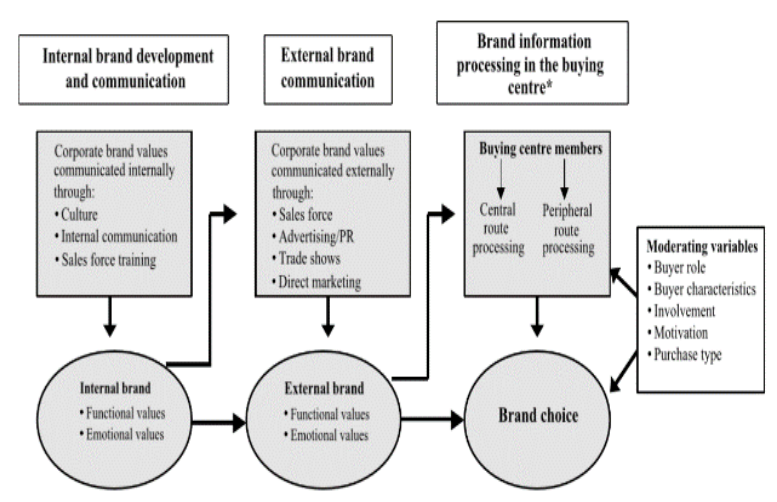

Sumber: Lynch dan Chernatony (2004, p.145)

Gambar 1. Brand Communication

\section{Customer Based Brand Equity}

The Customer Based Brand Equity telah diteleti lebih lanjut untuk secara khusus mengatasai bagaimana sebuah merek harus dibangun berdasarkan struktur pengetahuan customer (Keller, 2001a). Untuk membangun sebuah merek beradarkan pengetahuan konsumen, maka ada beberapa langkah yang dapat dilakukan. Pertama adalah mengidentifikai identitas brand dibenak konsumen, kedua adalah dengan tegas menetapkan kedua adalah menegaskan makna dari brand tersebut, dan yang ketiga adalah mencari tau bagaimana respon atau perasaan pelanggan terkait dengan nilai-nilai yang diberikan, kemudian langkah yang terakhir adalah menjalalin hubungan yang intens dan aktif antara pelanggan dan customer. Dalam bagan dibawah ini dapat kita lihat tiap dimensi pendukung dari maisng-masing langkah diatas. 

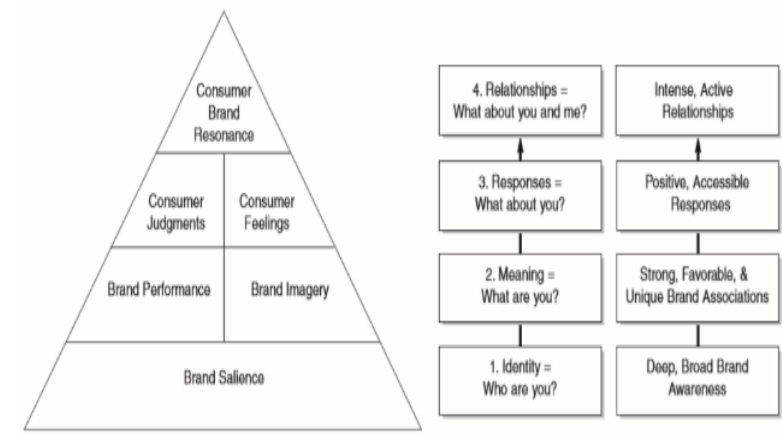

Gambar 2. Customer Based Brand Equity

\section{Customer Value}

Customer Value merpakan nilai yang dirasakan oleh pelanggan sebagai dua bagian konsep yang terdiri dari manfaat yang diterima (economic, sosial, dan relational) dan pengorbanan yang dilakukan (price, time, effort, risk, convenience) oleh pelanggan. Menurut Sanchez (2008) dimensi customer value terdiri dari:

1. Functional Value: kegunaan yang dirasakan dari atribut produk dan jasa, yang terdiri dari Functional value of establishment (installation), Functional value contact personel (professionalism), Functional value of the service purchased (quality), dan Functional value price (biaya).

2. Emotional Value: terdiri dari perasaan atau keadaan afektif yang diciptakan melalui pengalaman konsumsi yang dirasakan oleh pelanggan.

3. Social Value: penerimaan atau manfaat yang dirasakan pelanggan pada tingkat individu dengan lingkungan sosialnya.

\section{Customer Loyalty}

Customer Loyalty didefinisikan sebagai komitmen yang kuat dari pelanggan untuk melakukan pembelian ulang atau menjadi pelanggan sebuah produk atau jasa yang disukai secara konsisten di masa yang akan datang, meskipun pengaruh situasi dan usaha-usaha pemasaran mempunyai potensi untuk menimbulkan perilaku untuk berpindah (Oliver, 1999).

Sedangkan menurut Zeithaml (2000) dalam mengukur Customer Loyalty, bisa dilihat dari beberapa komponen yaitu:

1. Mengatakan hal yang positif tentang perusahaan kepada orang lain;

2. Memiliki rasa kepemilikan dan komitmen terhadap produk

3. Melakukan lebih banyak bisnis atau pembelian dengan perusahaan beberapa tahun mendatang.

\section{Kerangka Pemikiran}

\section{LATAR BELAKANG}

1. Proyek infrastruktur pemerintah akan melibatkan banyak tenaga ahli dalam negri.

2. Surabaya menjadi kota terbesar kedua yang berprospek tinggi di bidang property dan infrastruktur.

3. PT. Platinum Ceramics melakukan beragam kegiatan komunikasi pemasaran dengan para customer.

4. Tingkat loyalitas pelanggan yang miliki PT. Platinum Ceramics Industy penting untuk diketahui.

\section{RUMUSAN MASALAH}

1. Apakah Brand communication berpengaruh terhadap Customer Based Brand Equity pada PT. Platinum Ceramics Industry di Surabaya?

2. Apakah Brand communication berpengaruh terhadap Customer Value pada PT. Platinum Ceramics Industry di Surabaya?

3. Apakah Brand communication berpengaruh terhadap Customer Loyalty pada PT. Platinum Ceramics Industry di Surabaya?

4. Apakah Customer Based Brand Equity berpengaruh terhadap Customer Loyalty pada PT. Platinum Ceramics Industry di Surabaya?

5. Apakah Customer Value berpengaruh terhadap Customer Loyalty pada PT. Platinum Ceramics Industry di Surabaya?

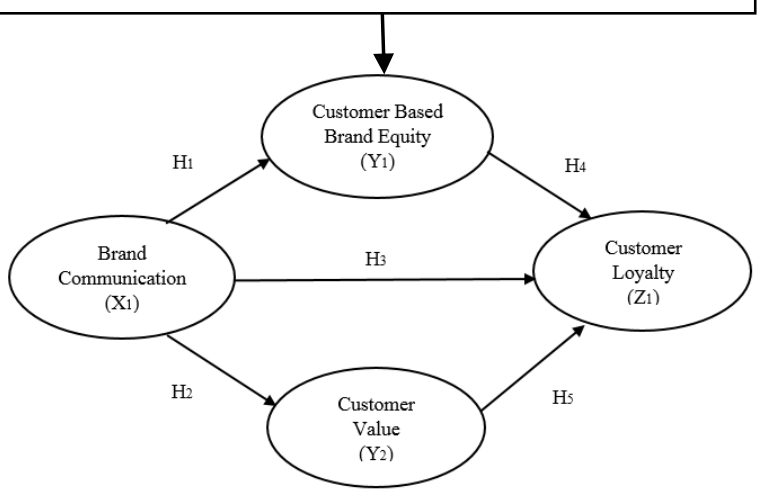

Sumber: Keller (2001, p.97)

Gambar 3. CBBE Pyramid

H1: Brand communication berpengaruh positif terhadap Customer Based Brand Equity

$\mathrm{H} 2$ : Brand communication berpengaruh positif terhadap Customer value

$\mathrm{H} 3$ : Brand communication berpengaruh positif terhadap Customer Loyalty

H4: Customer Based Brand Equity berpengaruh positif terhadap Customer Loyalty

H5: Customer value berpengaruh positif terhadap Customer Loyalty 


\section{METODE PENELITIAN}

\section{Populasi dan Sampel}

Populasi dalam penelitian ini adalah toko-toko yang pernah menjual produk keramik dari Platinum di Surabaya dan sampel dalam penelitian ini adalah toko-toko bangunan yang menjual produk Platinum dan berdomisili di Surabaya sejak tahun 2010. Tokotoko tersebut setidaknya sudah menjadi retailer selama kurang lebih 1 tahun terakhir pada saat pengisian kuisioner. Kuisioner akan dibagikan kepada 100 responden.Teknik pengambilan sampel pada penelitian ini menggunakan teknik non probability sampling.

\section{Definisi Operasional Variabel}

Definisi operasional variabel yang akan digunakan terdiri dari 4 variabel:

1. Variabel Independen:

Brand Communication (X1). Brand Communication adalah suatu tindakan yang dilakukan perusahaan untuk memperkenalkan produknya kepada para pelanggan dengan menggunakan beragam media.Dimensi dari Brandcom adalah Personal Selling, Advertising, Trade Show, dan Direct Marketing.

2. Variabel Intervening

Customer Based Brand Equity (Y1): Customer Based Brand Equity merupakan persepsi konsumen terhadap seluruh keunggulan yang dimiliki oleh suatu produk atau jasa berdasarkan pengetahuan yang dimilikinya. Dimensi dari Customer Based Brand Equity adalah Brand Salience, Brand Imagery, Brand Performance, Brand Feeling, Brand Judgment, dan Brand Resonance. Customer Value (Y2): Customer Value merupakan kepuasan yang dirasakan oleh pelanggan ketika mengkonsumsi suatu produk atau jasa. Dimensi dari Customer Value adalah Functional Value, Emotional Value, Social Value

3. Variabel Dependen

Customer Loyalty (Z1): Customer Loyalty adalah kesetiaan customer terhadap suatu brand dibandingkan dengan brand lainnya dalam bidang yang sama, yang dibuktikan dengan melakukan pembelian secara terus menerus. Dimensi dari Customer Loyalty adalah Saypositivething, Belonging and Commitment, Continue Purchasing.

\section{Teknik Analisi Data}

1. Path Analysis

Pengujuan statistik pada model path analysis dilakukan dengan menggunakan metode partialleastsquare. Partial Least Square (PLS) adalah metode alternatif dari SEM yang dapat digunakan untuk mengetahui komplesitas hubungan suatu konstrak dan konstrak lain, serta hubungan suatu konstrak dengan indikator-indikatornya (Abdillah \& Hartono, 2015).

2. Indikator Reliability dan Internal Consistency Reliability

Sebuah indikator dinyatakan memiliki reliable yang cukup baik apabila indicator reliability nilai 0,40 - 0,70 dan dikatakan baik apabila lebih besar dari 0,70. Kemudian, nilai internal consistency reliability didapat dari compositer eliability (Abdillah \& Hartono, 2015). Latent variabel akan dinyatakan reliabel apabila nilai composite reliability lebih besar dari 0,70 .

3. Convergent Validity \& Discriminant Validity

Ruleofthumb yang biasanya digunakan untuk menilai Convergent Validity adalah nilai loading factor yang harus lebih dari 0.7 atau nilai AVE yang harus lebih dari 0.5 untuk dikatakan valid. Variabel akan dinyatakan valid apabila nilai AVE yang telah diakar pangkat dua lebih besar (>) dari korelasi setiap latent variabel yang berhubungan. Sedangkan cara untuk menguji Discriminant Validity yaitu dengan melihat nilai crossloading untuk tiap variabel yang harus lebih besar dari 0.7 (Abdillah \& Hartono, 2015).

4. InnerModel atau Model Struktural

Innermodel atau model structural di evaluasi dengan menggunakan $R$-square untuk konstruk dependen, $Q$-Square predictive relevance untuk model struktural, dan uji t serta signifikansi dari koefisien paremeter jalur struktural Apabila nilai $\mathrm{R}^{2}$ berada diantara $0.25-0.50$, maka dinyatakan lemah, jika nilai $\mathrm{R}^{2}$ berada diantara $0.50-0.75$ dikatakan sedang, jika > 0.75 maka dinyatakan substansial. Perhitungan $Q$-Square dilakukan dengan rumus: $\mathrm{Q} 2=1-\left(1-\mathrm{R} 1^{2}\right)\left(1-\mathrm{R}^{2}\right) \ldots(1-$ $\mathrm{Rp}^{2}$ )

5. T-Test

T-test dilakukan dengan menggunakan metode bootstrapping. Apabila nilai bootstrap lebih dari (>) 1.96 maka variabel tersebut dinyatakan memiliki pengaruh yang signifikan, namun apabila nilai bootstrap lebih rendah $(<)$ dari 1.96 , maka varianel dinyatakan memiliki pengaruh yang lemah (Abdillah \& Hartono, 2015). 


\section{HASIL PENELITIAN DAN PEMBAHASAN}

\section{Profil Responden}

Dalam penelitian ini responden yang diteliti adalah para retailer atau toko-toko bangunan yang menjual Platinum di Surabaya, dimana para retailer ini telah menjual keramik Platinum selama lebih dari 5 tahun. Jangka waktu minimal 5 tahun ini bertujuan untuk memastikan bahwa responden yang diteleti benar-benar customer dari Platinum yang memiliki hubungan yang dekat dan telah merasakan sendiri pelayanan yang diterima dari waktu ke waktu, sehingga penilaian yang diberikan saat mengisi kuisioner dapat akurat. Pembagian kuisioner inipun dapat dikatakan cukup merata diseluruh wilayah di Surabaya, dengan pendistribusian sebagai berikut:

\begin{tabular}{cc}
\hline Wilayah & Jumlah Responden \\
\hline Surabaya Timur & 19 \\
Surabaya Barat & 16 \\
Surabaya Pusat & 26 \\
Surabaya Utara & 18 \\
Surabaya Selatan & 21 \\
Total & 100 \\
\hline
\end{tabular}

\section{Analisis Partial List Square (PLS)}

\section{Indicator Reliability}

Tabel 1. Indicator Reliability

\begin{tabular}{ccccc}
\hline $\begin{array}{c}\text { Latent } \\
\text { Variable }\end{array}$ & Indicator Loading & $\begin{array}{c}\text { Indicator } \\
\text { Reliability }\end{array}$ & Kesimpulan \\
\hline & X111 & 0,783 & 0,613 & Cukup \\
& X112 & 0,777 & 0,604 & Cukup \\
& X113 & 0,713 & 0,508 & Cukup \\
& X121 & 0,754 & 0,569 & Cukup \\
Brand & X122 & 0,812 & 0,659 & Cukup \\
Communication & X123 & 0,792 & 0,627 & Cukup \\
& X131 & 0,838 & 0,702 & Baik \\
& X133 & 0,747 & 0,602 & Cukup \\
& X141 & 0,750 & 0,558 & Cukup \\
& X142 & 0,727 & 0,563 & Cukup \\
& X143 & 0,799 & 0,638 & Cukup \\
& Y111 & 0,769 & 0,591 & Cukup \\
\hline & Y112 & 0,839 & 0,704 & Baik \\
& Y113 & 0,870 & 0,757 & Baik \\
& Y121 & 0,737 & 0,543 & Cukup \\
& Y122 & 0,841 & 0,707 & Baik \\
Bustomer & Y123 & 0,667 & 0,445 & Cukup \\
Yased Brand & Y131 & 0,738 & 0,545 & Cukup \\
Yquity (CBBE) & Y132 & 0,790 & 0,624 & Cukup \\
& Y133 & 0,893 & 0,797 & Baik \\
& Y141 & 0,864 & 0,746 & Baik \\
& Y142 & 0,879 & 0,773 & Baik \\
& Y143 & 0,657 & 0,432 & Cukup \\
& Y151 & 0,721 & 0,520 & Cukup \\
& Y152 & 0,700 & 0,490 & Cukup \\
\hline & & & &
\end{tabular}

\begin{tabular}{|c|c|c|c|c|}
\hline & Y153 & 0,677 & 0,458 & Cukup \\
\hline & Y161 & 0,644 & 0,415 & Cukup \\
\hline & Y162 & 0,830 & 0,689 & Cukup \\
\hline & Y163 & 0,762 & 0,581 & Cukup \\
\hline \multirow{9}{*}{$\begin{array}{c}\text { Customer } \\
\text { Value }\end{array}$} & Y211 & 0,756 & 0,572 & Cukup \\
\hline & Y212 & 0,840 & 0,706 & Baik \\
\hline & Y213 & 0,847 & 0,717 & Baik \\
\hline & Y221 & 0,783 & 0,613 & Cukup \\
\hline & Y222 & 0,685 & 0,469 & Cukup \\
\hline & Y223 & 0,776 & 0,602 & Cukup \\
\hline & Y231 & 0,790 & 0,624 & Cukup \\
\hline & Y232 & 0,764 & 0,584 & Cukup \\
\hline & Y233 & 0,829 & 0,687 & Cukup \\
\hline \multirow{9}{*}{$\begin{array}{c}\text { Customer } \\
\text { Loyalty }\end{array}$} & Z111 & 0,751 & 0,564 & Cukup \\
\hline & $\mathrm{Z} 112$ & 0,864 & 0,746 & Baik \\
\hline & $\mathrm{Z} 113$ & 0,825 & 0,681 & Cukup \\
\hline & $\mathrm{Z} 121$ & 0,738 & 0,545 & Cukup \\
\hline & $\mathrm{Z} 122$ & 0,840 & 0,706 & Baik \\
\hline & $\mathrm{Z} 123$ & 0,771 & 0,594 & Cukup \\
\hline & Z131 & 0,877 & 0,769 & Baik \\
\hline & Z132 & 0,844 & 0,712 & Baik \\
\hline & Z133 & 0,843 & 0,711 & Baik \\
\hline
\end{tabular}

Pada variabel Brand Communication terdapat 11 indikator yang memiliki tingkat reliabilitas yang cukup dan 1 indikator dengan tingkat reliabilitas baik. Kemudian pada variabel Customer Based Brand Equity dari total 18 indikator yang ada, 12 indikator memiliki tingkat reliabilitas yang cukup dan 6 indikator dengan reliabilitas baik. Selanjutnya, pada variabel Customer Value, sebanyak 7 dari 9 indikator yang ada memiliki tingkat reliabilitas yang cukup dan 2 indikator dengan reliabilitas baik. Pada variabel Customer Loyalty,7 indikator memiliki tingkat reliabilitas yang cukup dan 2 indikator dengan reliabilitas baik.

Dari Tabel 1, dapat dilihat bahwa secara keseluruhan indikator yang ada memiliki reliabilitas yang layak digunakan, sehingga dapat digunakan sebagai bahan untuk mengolah data selanjutnya.

\section{Internal Consistency Reliability}

Pada Tabel 2, dapat dilihat bahwa keseluruhan variabel yang ada memiliki nilai composite reliability diatas 0,7 . Oleh karena itu, dapat disimpulkan bahwa keseluruhan variabel memiliki level internal consistency reliability yang tinggi dan reliable.

Tabel 2. Internal Consistency Reliability

\begin{tabular}{lcc}
\hline \multicolumn{1}{c}{ Variabel } & $\begin{array}{c}\text { Composite } \\
\text { Reliability }\end{array}$ & Keterangan \\
\hline $\begin{array}{l}\text { Brand } \\
\text { Communication }\end{array}$ & 0,947 & Reliable \\
\hline $\begin{array}{l}\text { Customer Based } \\
\text { Brand Equity }\end{array}$ & 0,964 & Reliable \\
\hline $\begin{array}{l}\text { Customer Value } \\
\text { Customer Loyalty }\end{array}$ & 0,936 & Reliable \\
\hline
\end{tabular}




\section{Uji Validitas}

Tabel 3. Convergent Validity

\begin{tabular}{lcc}
\hline \multicolumn{1}{c}{ Variabel } & AVE & Keterangan \\
\hline Brand Communication & 0,598 & Valid \\
Customer Based Brand Equity & 0,601 & Valid \\
Customer Value & 0,619 & Valid \\
Customer Loyalty & 0,670 & Valid \\
\hline
\end{tabular}

Dari Tabel 3 dapat disimpulkan bahwa keseluruhan variabel yang digunakan dalam penelitian ini memiliki convergent validity yang layak. Setelah memastikan convergent validity, maka pemeriksaan validitas tahap selanjutnya dapat dilakukan.

Langkah berikutnya adalah menganalisa tabel Fornell-Larcker.Angka yang bercetak tebal di Tabel 4.didapatkan dari hasil akar pangkat dua nilai AVE pada latent variable, kemudian hasilnya dibandingkan dengan angka pada setiap latent variable lain yang berhubungan.

Tabel 4. Fornell-Larcker Criterion Analysis

\begin{tabular}{|c|c|c|c|c|}
\hline Variabel & $\begin{array}{c}\text { Brand } \\
\text { Communi } \\
\text { cation } \\
\end{array}$ & $C B B E$ & $\begin{array}{c}\text { Customer } \\
\text { Value }\end{array}$ & $\begin{array}{c}\text { Customer } \\
\text { Loyalty }\end{array}$ \\
\hline $\begin{array}{l}\text { Brand } \\
\text { Communication } \\
\text { Customer Based }\end{array}$ & 0,773 & & & \\
\hline $\begin{array}{l}\text { Brand Equity } \\
(C B B E)\end{array}$ & 0,710 & $\mathbf{0 , 7 7 5}$ & & \\
\hline Customer Value & 0,733 & 0,766 & 0,787 & \\
\hline Customer Loyalty & 0,628 & 0,695 & 0,719 & 0,818 \\
\hline
\end{tabular}

Dari Tabel 4 ini dapat dilihat bahwa akar AVE dari Brand Communication (0,773) lebih besar dari korelasi Brand Communication dengan Customer Based Brand Equity (0,710), Customer Value (0,733), dan Customer Loyalty $(0,628)$. Sehingga dapat disimpulkan bahwa variabel Brand Communication dapat dikatakan valid.

Begitu pula dengan akar AVE variabel Customer Based Brand Equity (0,775),Customer Value $(\mathbf{0 , 7 8 7 )}$, Customer Loyalty $(\mathbf{0 , 8 1 8})$ yang juga lebih besar dari korelasi variabel lainnya. Dengan demikian, semua variabel dapat dikatakan valid.

\section{Evaluasi Path Coefficient, Coefficient of Deter- mination $\left(R^{2}\right)$ dan Prediction Relevance $\left(Q^{2}\right)$}

Didalam penelitian bidang pemasaran, nilai $\mathrm{R}^{2}$ di atas 0,75 keatas dikategorikan substansial, 0,500,75 artinya sedang, dan $0,25-0,50$ artinya lemah.
Dari hasil analisa path coefficient ini dapat disimpulkan bahwa Customer Value dan Customer Based Brand Equity merupakan variabel intervening yang memperkuat hubungan antara Brand Communication dan Customer Loyalty. Nilai path coefficient ini menunjukkan bahwa pengaruh Brand Communication terhadap Customer Loyalty secara langsung tergolong kecil jika dibandingkan ketika hubungan tersebut melalui variabel Customer Value dan Customer Based Brand Equity terlebih dahulu.

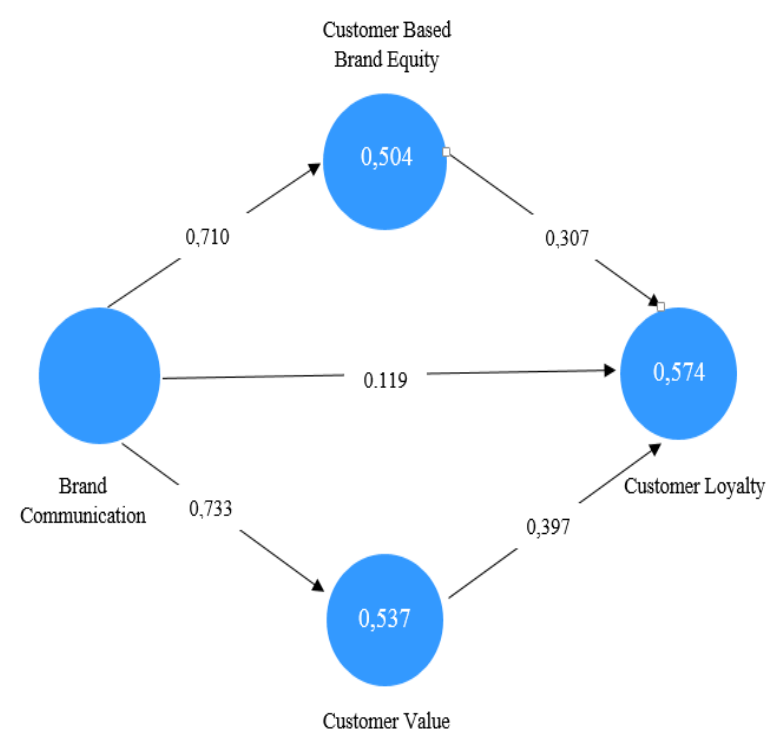

Gambar 2. Path coefficient dan Coefficient of Determination

Ketika hubungan tersebut melalui variabel Customer Based Brand Equity terlebih dahulu, maka nilai dari path coefficient meningkat menjadi 0,217 (= 0,710 x 0,307), sedangkn ketika hubungan Brand Communication melalui variabel Customer Value terlebih dahulu, maka nilai path coefficient akan meningkat menjadi $0,291(=0,733 \times 0,397)$. Sehingga dari seluruh perhitungan ini, dapat disimpulkan bahwa seluruh variabel dalam model ini memiliki path coefficient dengan angka yang positif.

Sementara itu, nilai coefficient of determination $\left(\mathrm{R}^{2}\right)$ dapat dilihat dari nilai di dalam lingkaran, dimana membuktikan bahwa variabel Customer Based Brand Equity dipengaruhi oleh Brand Communication dengan nilai varian sebesar 0,504. Lalu variabel Customer Value dipengaruhi oleh Brand Communication dengan nilai varian sebesar 0,537. Sedangkan variabel Customer Loyalty dipengaruhi oleh variabel Brand Communication, Customer Based Brand Equity dan Customer Value dengan nilai varian 0,574 . 


\section{T-statistics dan Uji Hipotesis}

Tabel 5. $T$-statistics

\begin{tabular}{|c|c|c|c|c|}
\hline & $\begin{array}{l}\text { Original } \\
\text { Sample } \\
\text { (O) }\end{array}$ & $\begin{array}{l}\text { Sample } \\
\text { Mean } \\
\text { (M) }\end{array}$ & $\begin{array}{l}\text { Standard } \\
\text { Error } \\
\text { (STERR) }\end{array}$ & $\begin{array}{c}\text { T Statistics } \\
(|\mathrm{O} / \mathrm{STERR}|)\end{array}$ \\
\hline $\begin{array}{l}\text { Brand Communi- } \\
\text { cation } \rightarrow \\
\text { Customer Based } \\
\text { Brand Equity }\end{array}$ & 0,710 & 0,711 & 0,050 & 14,215 \\
\hline $\begin{array}{l}\text { Brand Communi- } \\
\text { cation } \rightarrow \\
\text { Customer Value }\end{array}$ & 0,733 & 0,734 & 0,043 & 17,048 \\
\hline $\begin{array}{l}\text { Brand Communi- } \\
\text { cation } \rightarrow \\
\text { Customer Loyalty }\end{array}$ & 0,628 & 0,628 & 0,052 & 12,005 \\
\hline $\begin{array}{l}\text { Customer Based } \\
\text { Brand Equity } \rightarrow \\
\text { Customer Loyalty }\end{array}$ & 0,307 & 0,306 & 0,113 & 2,726 \\
\hline $\begin{array}{l}\text { Customer } \\
\text { Value } \rightarrow \\
\text { Customer Loyalty }\end{array}$ & 0,397 & 0,404 & 0,103 & 3,863 \\
\hline
\end{tabular}

Nilai T-statistics diperoleh dari prosedur bootstrapping, dimana nilai ini digunakan untuk menarik kesimpulan pada uji hipotesis. Nilai T-statistics dengan level signifikansi 5\% menjelaskan bahwa inner model akan signifikan jika nilai $T$-statistics lebih besar dari 1,96. Dari hasil diatas dapat dilihat bahwa setiap hipotesis memiliki pengaruh antara satu dengan yang lain.

Tabel 6. Kesimpulan Uji Hipotesis

\begin{tabular}{clc}
\hline Hipotesis & \multicolumn{1}{c}{ Keterangan } & T-statistics \\
\hline $\mathrm{H}_{1}$ & $\begin{array}{l}\text { Terdapat pengaruh dari Brand } \\
\text { Communication terhadap } \\
\text { Customer Based Brand Equity }\end{array}$ & 14,215 \\
\hline $\mathrm{H}_{2}$ & $\begin{array}{l}\text { Terdapat pengaruh dari Brand } \\
\text { Communication terhadap } \\
\text { Customer Value }\end{array}$ & 17,048 \\
\hline $\mathrm{H}_{3}$ & $\begin{array}{l}\text { Terdapat pengaruh dari Brand } \\
\text { Communication terhadap } \\
\text { Customer Loyalty }\end{array}$ & 12,005 \\
$\mathrm{H}_{4}$ & $\begin{array}{l}\text { Terdapat pengaruh dari Customer } \\
\text { Based Brand Equity terhadap } \\
\text { Customer Loyalty }\end{array}$ & 2,726 \\
\hline $\mathrm{H}_{5}$ & $\begin{array}{l}\text { Terdapat pengaruh dari Customer } \\
\text { Value terhadap Customer Loyalty }\end{array}$ & 3,863 \\
\hline
\end{tabular}

Dari hasil Tabel 6 dapat diketahui bahwa keseluruhan dari hipotesis telah terbukti dan memiliki pengaruh satu dengan yang lain.

\section{Pembahasan}

\section{Brand Communication terhadap CBBE}

Hasil penelitian ini menunjukkan bahwa variabel Brand Communication dari PT. Platinum Ceramics Industry memiliki pengaruh yang kuat terhadap Customer Based Brand Equity dengan hasil nilai uji $T$-statistics $>1,96$ yaitu sebesar 14,215. Hal ini menjelaskan bahwa beragam aktivitas pemasaran yang dilakukan oleh Platinum dalam rangka mengkomunikasikan produknya terhadap retailer haruslah mampu menciptakan persepsi yang baik dimata retailer. Dari keempat dimensi Brand Communicatioan dapat diketahui bahwa kegiatan advertising dan trade show merupakan dua aktifitas pemasaran yang memiliki tingkat efektifitas paling tinggi menurut para retailer, khususnya iklan Platinum di billboard terbukti sagat menarik perhatian masyarakat dikarenakan lokasi pemasangannya terdapai di banyak titik dan terletak pada lokasi yang padat sehingga dapat sangat cepat meningkatkan awareness dari masyarat serta kegitan launching yang dikemas secara menarik.

\section{Brand Communication dengan Customer Value}

Aktivitas Brand Communication yang dilakukan oleh Platinum ini selain menimbulkan persepsi yang positif dimata customer, juga dapat meningkatkan kepuasan dari para retailer. Misalnya saja dari bagaimana para sales person melayani para retail saat berkunjung. Keramahan dan ketanggapan sales dalam melayani retail tentunya berpengaruh besar terhadap kepuasan retail, terutama para sales disini berperan sebagai wakil dari perusahaan.

Oleh karena itu perusahaan harus benar-benar memperhatikan kinerja para sales dan mentraining setiap pegawai baru yang masuk. Hubungan yang dapat terjalin antara Brand Communication dengan Customer Value ini juga telah terbukti benar, karena telah diketahui bahwa kedua variabel ini memiliki path coefficient yang positif yakni sebesar 0,733 .

\section{Brand Communication dengan Customer Loyalty}

Walaupun memiliki pengaruh yang cukup kuat, namun Brand Communication tidak dapat mempengaruhi Customer Loyalty secara langsung, karena tanpa adanya persepsi yang baik dan kepuasan yang maximal dari para retail-retialnya tentu loyalitas tersebut tidak dapat didapatkan. Setiap iklan yang menarik ataupun event yang megah akan menjadi tidak ada artinya apabila perusahaan tidak mampu 
membangun persepsi serta menimbulkan kepuasaran melalui media-media komunikasi tesebut. Oleh karena itu pada penelitian ini besar pengaruh dari variabel Customer Based Brand Equity dan Customer Value terhadap Customer Loyalty.

Hasil analisa inipun juga telah dibuktikan pada saat melakukan pengukuran path coefficient.Pada bagan path coefficient dapat dilihat bahwa nilai dari Brand Communication menuju Customer Loyalty hanya sebesar 0.119 . Nilai ini menyatakan bahwa Brand Communication yang telah dilakukan oleh Platinum belum mampu secara langsung dan dengat kuat membangun loyalitas para retail.

\section{CBBE dengan Customer Lotalty}

Dari keenam dimensi Customer Based Brand Equity yang diteliti, dapat diketahui bahwa para mayoritas retail memiliki persepsi yang baik terhadap images dan performance yang dibangun Platinum selama ini. Dari hasi kuisioner yang telah dibagikan, para retail telah mengakui bahwa Platinum dikenal sebagai brand keramik dengan harga jual yang cukup bersaing (cenderung murah) namun memiliki kualitas produk yang premium. Beredarnya persepsi ini di masyarakat membuat Platinum menjadi brand yang populer dikalangan para retail bahkan dikalangan masyarakat luas.

Oleh karena itulah, para retailer cenderung terus setia untuk menjual produk Platinum karena selain karena produk ini diminati dipasar secara terus menerus, para retail juga merasa puas dengan performance dan pelayanan yang diberikan oleh Platinum selama ini, sehinnga kecil asalan bagi para retail untuk tidak setia menjadi retailer dari Platinum. Dari hasil analisa ini, dapat disimpulkan bahwa variabel Customer Based Brand Equity memiliki pengaruh yang positif terhadap Customer Loyalty dan hal ini dapat dilihat dari nilai path coefficient dari Customer Based Brand Equity terhadap Customer Loyalty sebesar 0,307.

\section{Customer Value dengan Customer Loyalty}

Kepuasan yang diberikan oleh Platinum terhadap para retail dapat dilihat dari berberap hal, seperti dari segi sosil value diaman para karyawan Platinum melayani para retailer dengan baik hingga akhirnya terjalin hubungan yang akrab antara para retail dengan karyawan. Selain itu dari segi Functional Value dapat diketahui pula bahwa para retail merasa puas karena produk dari Platinum sudah mampu menjawab kebutuhan pasar sehingga menimbulkan rasa percaya diri dalam diri retailer untuk menjual produk Platinum (emotional value).
Dari setiap kepuasan yang diterima oleh retailer baik itu dari segi functional, emotional, maupun sosial ini, tentunya bukan menjadi alasan bagi retailer untuk tidak loyal terhadap Platinum. Selain produknya yang laris di pasar, retailer juga mendapatkan pelayanan yang memuaskan, dan hal ini tentunya berdampak positif terhadap loyalitas retailer.Hubungan kedua variabel inipun diperkuat dari nilai path coefficient, yang menyatakan bahwa nilai Path dari Customer Value terhadap Customer Loyalty sebesar 0,397. Sehingga dari nilai path yang positif ini, dapat disimpulkan bahwa Customer Value memiliki pengaruh yang positif terhadap Customer Loyalty.

\section{KESIMPULAN DAN SARAN}

\section{Kesimpulan}

Berdasarkan dari hasil penelitian, dapat disimpulkan bahwa:

a. Brand Communication memiliki pengaruh yang positif terhadap Customer Based Brand Equity. Setiap rangkaian kegiatan pemasaran baik itu palayanan dari sales maupun iklan yang dilakukan oleh Platinum di berbagai billboard dan papan sopsign yang mampu menciptakan persepsi yang positif mengenai brand dimata retailer sekaligus meningkatkan awareness terhadap Platinum.

b. Adanya pengaruh positif antara Brand Communication terhadap Customer Value. Aktivitas Brand Communication yang dilakukan oleh Platinum dapat meningkatkan kepuasan dari para retailer khususnya dari pelayanan para karyawan, kegiatan retail gathering dimana pendapat para retail didengarkan, serta tingginya permintaan akan produk Platinum

c. Brand Communicationtidak dapat mempengaruhi Customer Loyalty secara langusung (nilai path hanya 0.119).

d. Adanya pengaruh positif antara Customer Based Brand Equity terhadap Customer Loyalty. Images yang baik mengenai Platinum dimata para retailer baik itu dari segi harga maupun kualitas produk membaut Platinum menjadi brand keramik yang populer hingga akhirnya membuat masyarakat menyukainya dan memiliki tingkat permintaan yang tinggi dibanding keramik lain, sehingga retail menjadi berani untuk menjual Platinum dan lama kelamaan menjadi loyal.

e. Pengaruh antara Customer Value terhadap Customer Loyalty menunjukkan pengaruh yang positif. Kepuasan yang dirasakan oleh para retailer baik itu dari segi functional, emotional, maupun sosial membuat retailer merasa puas dan nyaman, 
karena selain karena produknya diminati oleh pasar, retailer juga mendapatkan pelayanan yang memuaskan, sehingga hal inilah yang membuat para retailer menjadi loyal terhadap Platinum.

f. Dari seluruh pembahasan dalam penelitian ini, maka dapat disimpulkan bahwa Brand Communication merupakan variabel penting yang harus dikembangkan oleh Platinum untuk terus berkembang dan bisa menghadapi persaingan dalam industry keramik kedepannya, terutama untuk menghadapi masuknya keramik china ke Indonesia. Hal ini dibuktikan dalam penghitungan statistik bahwa implementasi Brand Communication berpengaruh positif terdahap Customer Based Brand Equity dan Customer Value yang meningkatkan Customer Loyalty.

\section{Saran}

Merujuk kepada hasil penelitian dan pembahasan, berikut ini adalah beberapa saran yang diajukan oleh peneliti:

1. Untuk PT. Platinum Ceramics Industry

Secara keselurahan aktivitas brandcom yang dilakukan sudah sangat baik dan memuaskan para retailnya, namun ada beberapa media komunikasi seperti instagram dan facebook yang dirasa para retail kurang sesusai karena tidak sesuai dengan target market. Selain itu penggunaan katalog produk sebagai media direct marketing juga perlu untuk diperhatikan, karena terdapat beberapa komplain dari pelanggan yang menyatakan bahwa ada beberapa motif gambar dikatalog yang kerap kali tidak sesuai atau tidak ada barang fisiknya.

Platinum juga harus memperhatikan sistem pendistribusian barang yang dilakukannya saat ini, karena beberapa pendistribusian barang tidak dihandle secara langsung oleh Platinum namun diberikan kepada para distributor. Hal ini dikhawatirnya dapat menjadi pemicu ketidakpuasan beberapa retailer terhadap pelayanan Platinum, karena kualitas pelayanan yang buruk dari distributor dapat mempengaruhi nama Platinum dimata para retailnya.

Platinum tetap harus menjaga kualitas dari produk keramiknya walaupun terdapat kenaikan bahan baku gas, karena kenaikan bahan baku gas yang mana telah menjadi permasalahan di dunia keramik saat ini dapat menigkatkan biaya produksi dari Platinum dan berpengaruh pada harga jual prosduk. Oleh karena itu Platinum harus mempertimbangkan solusi yang terbaik untuk menakan biaya produksi tanpa mempengaruhi kualitas dan harga jual.
2. Untuk Peneliti Selanjutnya

Peneliti selanjutnya dapat mengembangkan penelitian dengan menambah variabel diluar variabel yang digunakan dalam penelitian ini.Variabel yang mungkin bisa ditambahkan pada penelitian selanjutnya adalah Brand Trust atau Customer Engagement yang menjadi strategi perusahaan dalam mengambil tindakan implementasi lapangan. Penelitian tersebut akan melihat pengaruh dari strategi Brand Communication terhadap Customer Based Brand Equity dan Customer Value.

\section{DAFTAR PUSTAKA}

Abdillah, W., \& Hartono, J. (2015). Partial Least Square (PLS) - Alternatif Stuctural Equation Modeling (SEM) dalam Penelitian Bisnis (Cetakan 1). Yogyakarta: Penerbit Andy.

Azize, S., Cemal, Z., Hakan, K. (2012). Does brand communication increase brand trust? the empirical research on global mobile phone brands. The 8th International Strategic Management Conference, 58, 1361-1369.

Inilah 30 proyek besar pemerintah di bidang infrastruktur 2016-2019 (22 Februari 2016). Jurnal Politik. Retrieved February 22, 2016, from http://jurnalpolitik.com/2016/02/22/inilah30-proyek-besar-pemerintah-di-bidang-infrastruktur-2016-2019/.

Keller, K.L. (2001a). Building customer-based brand equity: A blueprint for creating strong brands. Marketing Management, July/August: 15-19.

Keller, K.L. (2012). Apakah brand equity dan keuntungan memiliki brand equity. Retrieved 27 August, 2012, from http://www.marketing.co.id/ kevin-keller-apakah-brand-equity-apa-sajakeuntungan-memiliki-brand-equity-2/

Lynch, J., \& Chernatony, D.L. (2004). The power of emotion: Brand communication in business-tobusiness markets. Brand Management,11(5), 403-419.

Oliver, R.L. (1999). Whence consumer loyalty?. Journal of Marketing, 63(5), 33-44.

Sanchez-Fernandez, R., Iniesta-Bonillo, M., \& Holbrook, M.B. (2008). The conceptualization and measurement of customer value in services. International Journal of Marketing Research, $51(1)$.

Zehir, C., Sahin, A., Kitapci, H. \& Ozsahin, M. (2011).The effects of brand communication and service quality in building brand loyalty through brand trust; the empirical research on global brands.The 7th International Strategic Management Conference, 24, 1218-1231. 
Zeithaml, V.A. (2000). Service quality, profitability, and the economic worth of customers: What we know and what we need to learn. Journal of the Academy of Marketing Science, 28(1), 67-85.
Zeithaml, V.A. (1988). Consumer perceptions of price, quality, and value: A means-end model and synthesis of evidence. Journal of Marketing, $52,2-22$ 